\title{
Комплексная устойчивость образцов ячменя из Эфиопии к биотическим и абиотическим стрессорам
}

Абдуллаев Р.А., к.б.н., н.с., Яковлева О.В., к.б.н., с.н.с., Косарева И.А., к.б.н., в.н.с., Коновалова Г.С., к.б.н., с.н.с., Радченко Е.Е., д.б.н., г.н.с. Федеральный исследовательский иентр Всероссийский институт генетических ресурсов растений им. Н.И. Вавилова, Санкт-Петербург, Россия. e-mail:abdullaev.1988@list.ru

В лабораторных и полевых опытах изучили устойчивость к ринхоспориозу, токсичным ионам алюминия и хлоридному засолению резистентных к мучнистой росе образиов ячменя из Эфиопии. Устойчивость к ринхоспориозу выявлена у 8 образиов. Нечувствительными к хлоридному засолению при двух конщентрациях соли (0,98 и 1,26\% NaCl) оказались 7 образцов, по устойчивости к токсичным ионам выделились две формы. Bыделены образиы, обладающие комплексной устойчивостью к мучнистой росе, ринхоспориозу, хлоридному засолению и токсичным ионам алюминия.

Ключевые слова: ячмень, устойчивость, мучнистая роса, ринхоспориоз, хлоридное засоление, токсичные ионы алюминия.

\section{Complex resistance of barley accessions from Ethiopia to biotic and abiotic stressors}

Abdullaev R.A., Yakovleva O.V., Kosareva I.A., Konovalova G.S., Radchenko E.E. Federal Research Center the N.I. Vavilov All-Russian Institute of Plant Genetic Resources, St. Petersburg, Russia e-mail: abdullaev.1988@list.ru

In laboratory and field experiments, the collection accessions of Ethiopian barley which are characterized by powdery mildew resistance were investigated for scald resistance and tolerance to chloride salinity and high content of toxic aluminum ions in the soil. Scald resistance was detected in eight accessions. Seven accessions turned out to be insensitive to chloride salinity at two salt concentrations, $0.98 \%$ and $1.26 \% \mathrm{NaCl}$; two forms stood out for resistance to toxic aluminum ions. The accessions possessing complex resistance to powdery mildew, scald, chloride salinity and toxic aluminum ions were identified.

Key words: barley, resistance, powdery mildew, scald, chloride salinity, toxic aluminum ions.

Ячмень (Hordeum vulgare L.) - одна из самых важных сельскохозяйственных культур в мире, урожай которой могут существенно снизить болезни, насекомые-вредители и эдафические стрессоры. Изучение генетиче- 
ских ресурсов растений с целью использования в селекции выделенных источников устойчивости к биотическим и абиотическим стрессорам - важное направление исследований.

Огромным разнообразием, многими ценными биологическими и агрономическими качествами, в том числе устойчивостью к ряду заболеваний характеризуются ячмени Эфиопии. В результате изучения 925 образцов ячменя из коллекции Всероссийского института генетических ресурсов растений имени Н.И. Вавилова (ВИР) к северо-западной популяции возбудителя мучнистой росы Blumeria graminis (DC.) Golovin ex Speer f. sp. hordei Marchal. выделили 27 устойчивых к B. graminis образцов, 47 форм были гетерогенны по изученному признаку. С помощью молекулярных маркеров выявили 15 образцов, несущих аллель mlol1, который обеспечивает длительную устойчивость к мучнистой росе большинства современных сортов ячменя [5].

Цель настоящих исследований - оценить устойчивость к ринхоспориозу (возбудитель - Rhynchosporium secalis (Oudem.) J.J. Davis), а также к хлоридному засолению и токсичным ионам алюминия образцов ячменя из Эфиопии, которые в наших экспериментах характеризовались резистентностью к мучнистой росе.

В лабораторных и полевых экспериментах на искусственном инфекционном фоне исследовали устойчивость 33 образцов ячменя к R. secalis. Растения инокулировали изолятами патогена, выделенными из северо-западной (Ленинградская область) популяции гриба. Устойчивость растений оценивали с помощью балловых шкал. Поражение до 2 баллов соответствует реакции устойчивости, 3-5 - реакции восприимчивости [2].

При изучении солеустойчивости 39 образцов ячменя использовали рулонный метод оценки [3], основанный на учете торможения роста корней в условиях солевого $(\mathrm{NaCl})$ стресса в сравнении с контрольными условиями, без засоления. Использовали два фона засоления - 0,7 и 0,9 мПа осмотического давления (соответственно 0,98 и 1,26 \% NaCl). По степени снижения среднего значения длины корешков образцы разделили на три группы: устойчивые, среднеустойчивые и чувствительные [1]. В первую группу вошли образцы, у которых длина корешков в растворе соли 0,9 мПа осмотического давления составляла $>60 \%$ по отношению к контролю, а в растворе 0,7 мПа -> 70 \%. Во вторую группу отнесли образцы с длиной корешков 40$60 \%$ в растворе соли 0,9 мПа, а при засолении 0,7 мПа осмотического давления $-50-70 \%$.

Диагностику алюмочувствительности 43 образцов H. vulgare проводили на ранних этапах развития растений с использованием корневого теста [4]. Длину зародышевых корней семидневных проростков, выращенных в растворе с содержанием 185 мкМ ионов алюминия $(\mathrm{pH}=4,0)$, соотносили с длиной зародышевых корней растений (определяли индекс длины корня - 
ИДК), выращенных в растворе без добавления солей алюминия $(\mathrm{pH}=6,5)$. Использовали также дополнительный тестовый признак - индекс длины ростка. Длину ростка и зародышевого корня измеряли одновременно. По степени устойчивости ячмени распределили на 5 групп.

Результаты опытов продемонстрировала высокую частоту резистентных к ринхоспориозу форм среди ячменей из Эфиопии. Устойчивостью к $R$. secalis обладали 8 образцов (к-8547, к-20029, к-23065, к-23450, к-25008, к27212, к-27670, к-29720), поражение которых составило 1-2 балла.

Нечувствительными к хлоридному засолению при 0,9 мПа осмотического давления оказались 15 изученных форм, 22 образца проявили себя как среднеустойчивые. В растворе соли с давлением 0,7 мПа в группу устойчивых вошли 8 изученных форм, 28 образцов были среднеустойчивы. Образцы к-17554, к-19975, к-20029, к-20048, к-22752, к-23450, к-25009 устойчивы при двух фонах засоления.

По показателю «индекс длины корня» наиболее устойчивы к токсичным ионам алюминия образцы к-8552 (ИДК $=0,82)$ и к-22933 (ИДК $=0,88)$. Подавляющее большинство изученных форм, отнесено к среднеустойчивой и устойчивой группам. По индексу длины ростка все образцы распределились в высоко устойчивую и устойчивую группы.

Таблица - Образцы ячменя из Эфиопии с комплексной устойчивостью к болезням и неблагоприятным эдафическим факторам

\begin{tabular}{|c|c|c|c|c|c|c|}
\hline \multirow{3}{*}{$\begin{array}{l}\text { № по } \\
\text { ката- } \\
\text { логу } \\
\text { ВИР }\end{array}$} & \multirow{3}{*}{ Образец } & \multicolumn{5}{|c|}{ Устойчивость к } \\
\hline & & \multirow[t]{2}{*}{$\begin{array}{l}\text { R. secalis, } \\
\text { балл }\end{array}$} & \multicolumn{2}{|c|}{$\begin{array}{c}\mathrm{NaCl} \text { (длина ко- } \\
\text { решка в сравнении } \\
\text { с контролем), \% }\end{array}$} & \multicolumn{2}{|c|}{$\begin{array}{c}\mathrm{Al}^{3+} \text { (индекс } \\
\text { длины) }\end{array}$} \\
\hline & & & 0,7 мПа & 0,9 мПа & ростка & корня \\
\hline 23450 & H.2866 Coll.Halle EP80 & 1 & 85 & 62 & 0,92 & 0,41 \\
\hline 27670 & AHOR 416/67 & 2 & 67 & 44 & 0,89 & 0,67 \\
\hline 29720 & Ethiopia AB.2193 & 1 & 69 & 62 & 0,87 & 0,56 \\
\hline \multicolumn{2}{|c|}{ Cambrinus (воспр. контроль) } & 4 & - & - & - & - \\
\hline \multicolumn{2}{|c|}{ Одесский 70 (уст. контроль) } & - & 66,1 & 49,5 & - & - \\
\hline \multicolumn{2}{|c|}{ Полярный (уст. контроль) } & - & - & - & 0,98 & 0,91 \\
\hline
\end{tabular}

В таблице представлены образцы ячменя из Эфиопии с комплексной устойчивостью к болезням и абиотическим стрессорам. Все изученные формы устойчивы к мучнистой росе. Образцы к-23450 и к-29720 защищены геном устойчивости к грибу mlo1 1 [5], образец к-27670 имеет другой эффективный ген (гены) устойчивости к $B$. graminis. Выявленные нами формы представляют большой интерес для селекции в различных зонах России.

Благодарности: Исследование выполнено при поддержке РФФИ (грант № 18-016-00075) и бюджетного проекта № 0662-2019-0006. 


\section{Список литературы}

1. Давыдова Г.В., Коваль В.С., Лукьянова М.В. Ячмень. Характеристика селекционных и местных сортов на солеустойчивость. Каталог мировой коллекции ВИР. - Вып. 605. - Л: ВИР. - 1991. - 34 с.

2. Коновалова Г.С. Ринхоспориоз. В кн.: Изучение генетических ресурсов зерновых культур по устойчивости к вредным организмам. Методическое пособие. М.: Россельхозакадемия. - 2008. - С. 129-135.

3. Удовенко Г.В., Волкова А.М. Определение в раннем возрасте солеустойчивости зерновых злаков по комплексу ростовых параметров. Методические указания. - С.-Петербург: ВИР. - 1993. - 15 с.

4. Яковлева О.В., Ковалева О.Н. Ячмень. Характеристика образцов ячменя по устойчивости к токсичным ионам алюминия $\left(\mathrm{H}^{+}+\mathrm{Al}^{3+}\right)$. Каталог мировой коллекции ВИР. - Вып. 824. - С.-Петербург: ВИР. - 2015. - 24 с.

5. Abdullaev R.A., Lebedeva T.V., Alpatyeva N.V., Yakovleva O.V., Kovaleva O.V, Radchenko E.E. et al. Genetic diversity of barley accessions from Ethiopia for powdery mildew resistance // Russian Agricultural Sciences. - 2019. - V. 45. - №3. - P. 232-235. DOI: 10.3103/S1068367419030029.

DOI 10.18699/GPB2020-02

\section{Оценка образцов свеклы на хладостойкость}

Абекова А.М. * к.с.-х.н., с.н.с. аналитической лаборатории группь биотехнологии и молекулярно-биологического анализа; Ержебаева Р.С. к.б.н., руководитель аналитической лаборатории группь биотехнологии и молекулярнобиологического анализа; Берсимбаева Г.Х. ст. лаборант аналитической лаборатории группь биотехнологии и молекулярно-биологического анализа.

Казахский научно-исследовательский институт земледелия и растениеводства, п. Алмалььбак, Казахстан.

*e-mail:aabekova@mail.ru

Изучена холодостойкость 43 гибридов и линий сахарной свекльв в лабораторных условиях с использованием оценки прорастания семян при пониженных температурах и культуры іп vitro. По результатам оченки прорастания при температуре $+4^{\circ} \mathrm{C}$ отобраны холодостойкие образцы с наиболее высокой всхожестью семян (6,5-21,5\%), при контроле 46,6$100 \%$. На основе оиенки культуры іn vitro при низких температурах $+4^{\circ} \mathrm{C}$ отобраны 5 образцов, показавиих высокий уровень формирования пазушных почек (3-4 шт.). Вылеленные образиы могут быть использованы для селекцчии на холодостойкость.

Ключевые слова: Сахарная свекла, холодостойкость, прорастание, культура in vitro, отбор. 